\title{
ACSL6/ETV6 Fusion Gene
}

National Cancer Institute

\section{Source}

National Cancer Institute. ACSL6/ETV6 Fusion Gene. NCI Thesaurus. Code C99676.

A fusion gene that results from a chromosomal translocation $\mathrm{t}(5 ; 12)(\mathrm{q} 31 ; \mathrm{p} 13)$ which fuses the 5' portion of the ACSL6 gene and the 3' portion of the ETV 6 gene. In a patient with acute myelogenous leukemia with eosinophilia, this rearrangement fused exons 1-9 of the ACSL6 gene to either intron 2 or exon 3 of the ETV6 gene and does not produce a fusion protein. In one patient with refractory anemia with excess blasts with basophilia, this rearrangement fused exon 19 of the ACSL6 gene with a site within exon 1 of the ETV6 gene and could result in the production of a fusion protein. 